\title{
HUBUNGAN KEBIASAAN KONSUMSI MAKANAN TINGGI LEMAK JENUH DENGAN KADAR KOLESTEROL TOTAL PENDERITA PENYAKIT JANTUNG KORONER RAWAT JALAN DI BLUD RSUD MEURAXA BANDA ACEH
}

\author{
Cut Mukminah ${ }^{1}$, Silvia Wagustina ${ }^{2}$ \\ 1,2 Jurusan Gizi, Politeknik Kesehatan Kemenkes Aceh, JL. Soekarno Hatta, Kampus Terpadu Poltekkes \\ Kemekes Aceh RI Aceh Lampeneurut, Aceh Besar. Telp.065146126. kode pos 23352
}

\begin{abstract}
ABSTRAK
Masyarakat Aceh mempunyai kebiasaan mengkonsumsi makanan tinggi lemak jenuh seperti gulai kambing yang mengandung daging berlemak, otak, jeroan. Hal ini dikarenakan aktivitas kerja yang penuh, perubahan gaya hidup dan ekonomi yang meningkat. Pola makan itu dapat menyebabkan kolesterol didalam darah akan meningkat dan menyebabkan penyumbatan pada dinding pembuluh darah jantung. Tersumbat pembuluh darah arteri koronaria jantung maka menyebabkan penyakit jantung koroner. Rancangan Penelitian ini deskriptif analitik dengan pendekatan crossectional. Sampel adalah penderita penyakit jantung koroner. Jumlah sampel 32 orang. Pengambilan sampel secara purposif sampling. Jenis data yang dikumpulkan terdiri atas data primer yaitu kebiasaan konsumsi makanan tinggi lemak jenuh dan data sekunder yaitu kadar kolesterol total. Analisis data dalam penelitian ini menggunakan fisher's exact test. Penyajian data disajikan dalam bentuk tabular dan tekstular. Hasil penelitian 29 orang mempunyai kebiasaan konsumsi makanan tinggi lemak jenuh tinggi dan kadar kolesterol total tinggi. Rerata konsumsi lemak jenuh 22,9 gr dan kadar kolesterol 246,22 mg/dl. Dimana konsumsi lemak tertinggi $30 \mathrm{gr}$, terendah $8 \mathrm{gr}$ dan kadar kolesterol total tertinggi $310 \mathrm{mg} / \mathrm{dl}$, terendah $187 \mathrm{mg} / \mathrm{dl}$. Ada hubungan dengan $p<0,05$. Kesimpulan terdapat hubungan kebiasaan konsumsi makanan tinggi lemak jenuh dengan kadar kolesterol total pada penderita penyakit jantung koroner rawat jalan.
\end{abstract}

Kata Kunci : Kebiasaan, Konsumsi, Kolesterol Total

\begin{abstract}
The people of Aceh have the habit of eating foods high in saturated fats such as curry goat containing fatty meat, brain, viscera. This is because the activity of full employment, lifestyle changes and increased economic. A diet that can lead to cholesterol in the blood will increase and cause blockages in heart blood vessel walls. Clogged blood vessels, the heart coronary arteries cause coronary heart disease. The design of this study was cross sectional descriptive analytic approach. Samples are people with coronary heart disease. Number of samples 32. Sampling was purposive sampling. Types of data collected consist of primary data consumption habits of foods high in saturated fat and secondary data, total cholesterol levels. Analysis of the data in this study using Fisher's exact test. Presentation of data is presented in tabular form and tekstular. Results of the study 29 people have a habit of consumption of foods high in saturated fat and high total cholesterol level. The mean consumption of 22.9 grams of saturated fat and cholesterol content of $246.22 \mathrm{mg} / \mathrm{dl}$. Where the highest consumption of 30 grams fat, 8 grams lowest and the highest total cholesterol $310 \mathrm{mg} / \mathrm{dl}$, the lowest $187 \mathrm{mg} / \mathrm{dl}$. There is a relationship with $p<0.05$. Conclusion correlation habit of consumption of foods high in saturated fat with total cholesterol levels in patients with coronary heart disease outpatients.
\end{abstract}

Keywords : Habits, Consumption, Total Cholesterol

AcTion Journal, Volume 1, Nomor 1, Mei 2016 